Virve Sarapik

\title{
ARTIST AND MYTH
}

This is a copy of the article from printed version of electronic journal

\section{Folklore Vol. 15}

ISSN 1406-0957

Editors Mare Kõiva \& Andres Kuperjanov

Published by the Folk Belief and Media Group of ELM

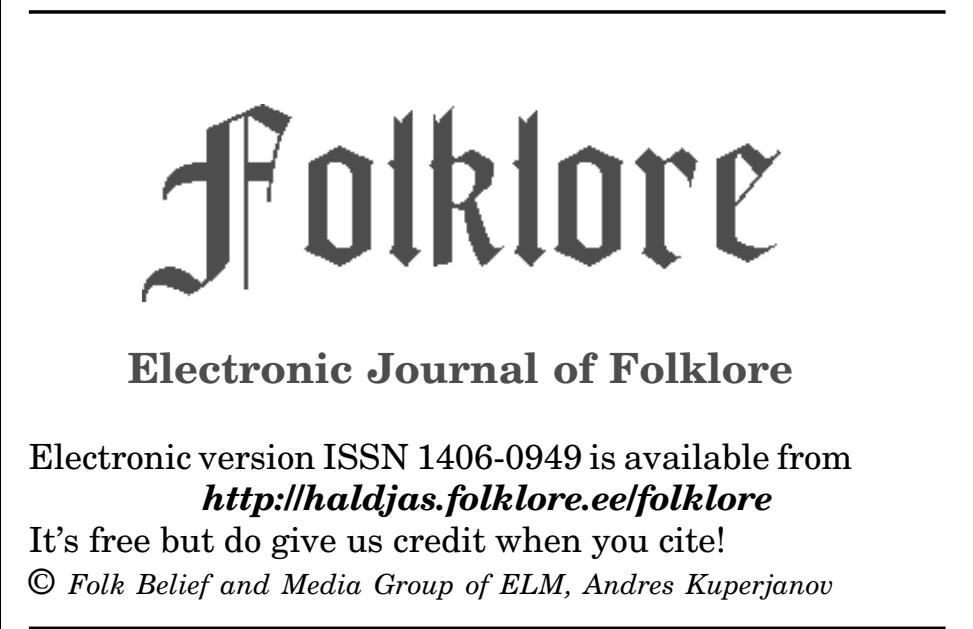

\section{Tartu 2000}




\section{ARTIST AND MYTH}

\section{Virve Sarapik}

\section{1.}

In the case of myth we can clearly distinguish at least two usages: on the one hand myth is used in its classical meaning, the one that most people are generally in agreement on, and on the other hand we can find phenomena prevalent even in today's society that seem to resemble classical myths. A cursory glance at such myths amply demonstrates the radically divergent precepts around them. From this diversity it is obvious that the question is going to crop up whether all of the phenomena subsumed under myth should be lumped together as being part of one concept and whether myth is the best word to express this concept. While I remain sceptical in this regard, I nonetheless, would hesitate to offer any radically alternate suggestion. As far as myth is concerned, we will use as our point of departure those phenomena that diverse authors have considered as myths without discussing whether they could be better expressed by some more appropriate term or whether they could converge somehow in the semantic field of some other concept. It is quite possible that the multifacetedness of myth derives from the change over of the original Greek word mythos from speech to (an imaginary) story.

Perhaps one of the sources of the divergence in the meaning of myth might be hidden in the dual function it originally had. In very broad terms these are:

- poetic or narrative

- explanatory or cognitive

One possibility allowing myth to survive today lies in its ability to continue as a narrative. This is what we find for example in film series, comics, detective novels or other stories produced by mass culture (for example Eliade 1963: $191 \mathrm{ff}$ ), Another possibility lies in its ability to continue as a cognitive element, that is, the part of the myth used to explain the world. One common meaning of myth associated with its cognitive aspects is that of myth as a deception, 
distortion or falsehood. We can see the origins of this meaning when the ancient mythos diverged from logos. This became firmly estblished during the middle ages when the word myth became associated with a pagan lie. We could now say that today's theory of the myth is open but even though it would appear that we are dealing with one and the same thing our conclusions can often be diametrically opposed.

Perhaps a few examples would help here. The two most prevalent understandings of ideological or political myths come from the works of George Sorel and Roland Barthes (Sorel 1990; Barthes 1982). The ideological underpinnings of both Sorel and Barthes were relatively similar - the left and a critical approach to bourgeois society. Despite this, they managed to create two very distinct dichotomies between myth and politics that reflect changed historical circumstances.

Sorel was interested in finding out why people were ready to offer their lives in the name of some ideal that require them to shun their rational egoism and normal practices. He came to the conclusion that only some myth could cause a person to step beyond the bounds separating speech and action, to step beyond rational considerations. He found that revolution without myth is not possible. This was revealed in Sorel's hate for language and politics - and paradoxically here was the premonition of a totalitarian regime. After all, a disdain of words, the slogan "from words to deeds" was one of the roots of totalitarianism. Barthes' myth on the other hand worked in the name of bourgeois ideology at the same time as being perhaps a direct and perhaps unconscious conspiracy on the part of the bourgeois as a class against the individual in society. Of course we might want to consider Barthes' mythologies specific to his times if he himself had not hurried to make further far-reaching generalisations about both the myth-free nature of the left as well as the linguistic elements of myth.

A comparison of the relationship myths have to language provide us with another example of a different approach.

In some ways both myth and language are similar types of words. Both language and myth have a core of languageness and mythness that everyone agrees on. At the same time, both have an endless 
supply of hypostases in which these words are used with either a more literal or more metaphoric meaning. In some instances, the original metaphor has become so worn away that the difference between their literal and extended meaning becomes indiscernible. There are plenty of examples of the word language used where the languageness of the thing discussed is completely non-existent.

If Sorel's left-leaning myth was connected to going beyond language or moving from words to deeds then Barthes' myth in contrast was language-specific. To be sure, Barthes' theory has often been criticised for its inconsistencies in that Barthes considers myth to be the speech-act, the message, a meta-language and a semiological system. In any case, Barthes' whole system of myth rests on language where it is in a position to produce even more additional meanings. In contrast to myth as Barthes sees it, we have for example modern poetry, which has become a regressive semiotic system at the stage of pre-semiological language (Barthes 1982: 120121).

Language leads us directly to Claude Lévi-Strauss, who also dealt with myth. But while the basis of Lévi-Strauss' theory was an unmotivated system of myth symbols or mythemes (e.g. Lévi-Strauss 1972: 206-231, 1970: 1-32), then Barthes on the other hand, feels that no myth can exist unless it is based on some motivating relationship (Barthes 1982: 112-113).

A third example is provided by Juri Lotman and Boris Uspenski who feel that myth is asemiotic and as such is very reminiscent of that anomalous layer in language, proper names (Lotman \& Uspenski 1992: 62). Lotman and Uspenski associate proper names with myth by using child-language as an example. Much of what is in the child's consciousness could be compared to a consciousness of myth. In the same way, child language at a certain stage resembles proper names.

2.

These two examples should be enough to convince us of the wide range of meaning behind myth today. In admitting this, we can now move on to look at myth in art. And here I am not referring to a 
secondary use of myth as an object of depiction in art but rather to the continued existence of a texture characteristic of some living myth within art itself. And since our main object of interest here is the author or rather artist, than the main focus will be on the myth of the artist. A second focus will be on the differing opinions mentioned above with respect to the connection between myth and language. The similarity between myth and proper names that Lotman and Uspenski observed can lead us to the logical connection between the name of an author and the myth of the artist. I will take a book by Ernst Kris and Otto Kurz as my point of separture (the book first appeared in 1937, Die Legende vom Kunstler: Ein historischer Versuch - Kris \& Kurz 1979). The principles presented in this relatively obscure work seem to be universal even today.

Kris and Kurz examined primarily ancient and renaissance artists or rather the stories about artists that were prevalent during the ancient and renaissance periods. The richest source of stories about artists of the ancient period are found in Pliny the Elder's Naturalis historia. Book 35 and in part books 33 and 34 are devoted entirely to them. An inexhaustible source for biographies of renaissance artists is without a doubt Giorgio Vasari's lives of artists (Le Vite de' più eccellenti architetti, pittori, et scultori italiani, first publishes in about 1550 followed by an enlarged edition in 1568 - Vasari 1927). It is quite evident that Vasari was the one that established much about artists that has remained canonic right to the present.

Kris and Kurz found that a number of wide-spread and coinciding motifs can be pointed out in the artists' biographies (they mostly studied the artists of ancient times and the Renaissance). After some adaptation, the motifs could be the following:

\section{I - The Heroization of the Artist's Biography}

As subsections here we can distinguish the following:

- unusual background: (as repeating motifs we come across things such as illegitimacy, poverty, serious illness in childhood). As such, some premonition of an extra-ordinary future is apparent already in childhood;

- an early talent in arts that is manifested in some very noticeable fashion (the artist sketches animals as he is tending the herd, 
doodles on the walls - as with Filippi Lippi or doodles in notebooks Poussin, Michelangelo; this passion for drawing is often actively discouraged, for example the child is beaten by the father);

- the artist meets a benefactor or teacher who recognized the child's talent and who in later life becomes a significant force, often assuming the role of the father. Part of this is the often repeated admission of the teacher that he has no more that he can teach the future artist.

An appropriate example of this, albeit from a significantly later period, is provided by the description of Pablo Picasso's childhood:

The heavy rain that had been falling a few days earlier had given way to a strong easterly wind. Night had fallen early and it was dark. It was a heavy autumn night in the city of Malaga. At number 36 in the Plaza de Riego ... , there was an atmosphere of tension and uncertainty. Doña María Francisca Picasso López was lying in childbed. [---] The birth was not easy but at a quarter past eleven on that autumn night it was all over. A new baby, another son of the city of Malaga, had come into the world. [---] That night, Tuesday October 25th, saw the start of the life of the man who, with time, would become a myth, and like all myths, a legend. His uncle Salvador Ruiz Blasco, a qualified doctor, attended the birth and made sure, with his skill, that the newborn baby survived." (Mallen 1999a) "His unusual adeptness for drawing began to manifest itself early, around the age of 10, when he became his father's pupil [Picasso's father was professor of Drawing José Ruiz Blasco] ... At this time he started his first paintings. From that point his ability to experiment with what he learned and to develop new expressive means quickly allowed him to surpass his father's abilities. (Mallen 1999b)

One of the favourite motifs in the childhood stories of Renaissance and later-day artist was the tending the herds. Probably the most famous of these childhood shepherds in the history of art is Giotto. Vasari describes in a very lively fashion how Giotto loved to draw animals as he tended them. It was there that his future teacher, the artist Cimabue discovered the boy: “... and while the sheep were grazing, [Giotto] was drawing one of them with a roughly sharpened piece of stone on the smooth surface of the cliff, even though 
apart from Nature he had no other teacher." (Vasari 1927: I, 66.) This fact found its way into the eleventh canto of Dante's Divine Comedy.

The herder and in particular the shepherd motif was particularly successful in artists' biographies for centuries. In Vasari we can find the same episode in the biographies of Andrea Sansivono and Andrea del Castagno, Mantegna was a shepherd, Raffaellino da Reggio was a goatherd, and from later periods we know that Zurbarán and Goya were also herders (Kris \& Kurz 1979: 26-38).

Another story was circulated about Giotto. According to this version Giotto was supposed to have become a wool merchant but he ran away from the workshop in order to paint (Kris \& Kurz 1979:24).

In the descriptions of the artists' lives, the facts are not important but rather how they can be made to follow the canons and preconceived notions that were already prevalent assumes importance. We find instead of accuracy, mythical motifs. In Giotto's times and in the following centuries a spirit of pastoralism was floating over Europe and so it was inevitable that the artists had to be sent to tend herds too. The post-Freudian myth of the artist today is obviously going to be different in comparison to that of the renaissance. The premonitions and influences are going to be different, but they will be there nonetheless. As a premonition at birth, the place of birth has often become significant today. A mythical glitter is added to the biographies of western European and American artists by virtue of their being born in eastern Europe or Russia.

As an example of this and how facts can be made to be slippery, let us look at the biography of Mark Rothko. The following excerpts are taken from the Internet where the raw data found being disseminated there provides a fertile terrain for the growth of folklore. The sources we have chosen are, however, among the more trustworthy ones (i.e. net-encyclopaedia and websites of galleries):

1. "The artist was born in Dvinsk, Russia [---] As a student of Josef Albers, Rothko's work may seem at first glance much like that of his mentor. "

2. "American Abstract Expressionist painter, born at Dvinsk in Russia. [---] Studied the liberal arts at Yale University 1921-3. Moved 
in 1925 to New York and studied for a short time at the Art Students League under Max Weber, then began to paint on his own."

3. "born Sept. 25, 1903, Dvinsk, Russia ... American painter [---] In 1913 Rothko's family emigrated from Russia to the U.S., where they settled in Portland, Ore. During his youth he was preoccupied with politics and social issues. He entered Yale University in 1921, intending to become a labour leader, but dropped out after two years and wandered about the U.S. In 1925 he settled in New York City and took up painting.

4. "Mark Rothko was born Marcus Rothkowitz in Dvinsk, Russia (today Daugavpils, Latvia), on September 25, 1903 ... Rothko and his family immigrated to the United States when he was ten years old, and settled in Portland, Oregon. Rothko attended Yale University in 1921, where he studied English, French, European history, elementary mathematics, physics, biology, and economics, the history of philosophy, and general psychology. His initial intention was to become an engineer or an attorney. Rothko gave up his studies in the fall of 1923 and moved to New York City."'

If we set aside the fact of Dvinsk and Russia, which tends to offend the Baltic amour-propre (similar sorts of examples can be culled from the biographies of Estonian and Baltic Germans in Dorpat), the most curious fact seems to be the one making Rothko out to be one of Josef Albers' students. But Albers immigrated to America only in 1933 after the closing of Bauhaus and he was the director of Yale's design department between 1950-1960. Thus, we see in addition to emphasizing his Russian origin (even though Rothko was actually a Latvian Jew, the necessary irrationality emanated from Russia) it was also important to find a familiar teacher and leader for him.

It is natural that in the post world War II biographies of artists there is going to be a shift in emphasis as compared to the renaissance. Among American artist there are many who died young (for example Arshile Gorky's suicide, Jackson Pollock's car accident) or drank and took drugs. These same shifts have occurred in pop culture and literature, but the significance lies elsewhere - the symbolic elements have shifted from birth to death and in the direction of tragic signs (sickness, childhood abuse, the death of someone 
dear etc.). If previously birth had been the prelude to life, then in the second half of the 20th century, life itself had become a prelude to death. It is true that in previous centuries there were many artists who had short lives but their premature death had never been fetishized to the extent it is now. By way of comparison, we can look at the sicknesses and deaths inspired by romanticism. This is, to be sure, more prevalent in literature. In the world of art the best-known example of it would be the life of van Gogh.

Two examples from the beginning of the introductory materials for an exposition in the Washington National Gallery are sufficient to demonstrate the above:

"Rothko, who committed suicide at age sixty-six, was born in Dvinsk, Russia, and immigrated to the United States at age ten. After two years of liberal arts study at Yale University, he moved to New York, ..." the introduction to Jackson Pollock begins with the announcement of his death, which appeared 20 August 1956 in Time Magazine. $^{2}$

To summarize the basic points of the heroic artist's biography:

- the hero demonstrates talent at an early age

- often poor from a lower social class

- undergoes a turning point through meeting a helper, advisor, teacher (this provides a bipolarity to the biography whereby the artist's personality is allowed to rise out of his humble beginnings and the raising up is carried out by the helper)

- premonitions and the helper/guide is present at the beginning of all biographies.

It is through these elements that we are convinced that the artist is not like other ordinary people, and, after all, the artist in any society can allow himself something more than others can. In this way the hero motif is connected to the artist myth.

The birth of Michelangelo assumes truly mythic proportions in the biography by Vasari:

At that time, while the diligent and chosen spirits, helped by that enlightenment which Giotto and his followers had created, hoped to demonstrate those talents to the world with which auspicious 
stars and their own equilibrate nature had provided them ... the great Heavenly lawgiver looked down and upon seeing the vain and fruitless exertions and arrogant opinions of men which verily were further from truth than light is from dankness, decided in order to free them of these faults to send a genius equal in all arts into the world. God equipped him with a just and moral philosophy and a pleasing poetic disposition so that the whole world would be enchanted with the outstanding and uniqueness of his life and work and all his achievements and that they would seem rather divine in origin than earthly.

Tuscany has always been at the forefront of the painting, sculpting and architectural arts and Firenze was the Italian city, more than any other, for her crowning achievements, worthy of being the birthplace of such a citizen. And so in the year 1474 the honourable and virtuous wife of Ludovico di Lionardo Buonarrotti Simone gave birth to a son under most auspicious stars. This son of whom I speak was born on Sunday the sixth of March around eight of the clock in the evening. He was give in the name Michelangelo as was suitable for a creature of divine nature since Mercury and Venus were in the house of Jupiter at the moment of his birth signifying that his works of art would be prodigious." (Vasari 1927: IV, 108.)

Enn Kasak has depicted the birth of Navitrolla in an interesting Vasari-like key:

From the Beginning till the End, Harmony and Chaos wrestle in the world of humans. Each of us will choose a side suitable for ourselves. It is easy to burn our time vindicating ourselves and enjoying life. This is the way of the many. Seldom one finds people who, through hard work, create islets of order and clarity amidst slackness and decay. [---] 1970 years after Christ, on the 10th of August in Vorru (a little province which is the capital of Southern Estonia) a boychild is born, who, according to the documents, is a human unit with the name Heiki Trolla. But according to his deeds, a person with the name Navitrolla. His Vorro descendants were peasants and his parents have become peasants again. In his very early years Navitrolla was seriously ill many times, but he recovered despite free medical care and enthusiastic doctors. (I remember well how this little boy always 
starts to scream desperately when seeing white overalls - his first cognizant experience of color.) (Kasak 1995: 20).

We can find lots of stories about Estonian artist who grew up in poverty and tended herds as children. The situation in Estonia even at the beginning of the twentieth century made this the only possible path for the most part. Even if the herder motif appears less often, almost obligatory is the finding of a helper/guide. We need but recall the debate only just recently on the occasion ofAdo Vabbe's 100th birthday to decide whether he had met and been influence by Kandinsky or not. The person most responsible for establishing this myth was the Baltic-German art critic von Stryk who named Vabbe as Kandinsky's favourite pupil (Stryk 1918).

The source of myths for the 50's generation of Estonian artists is usually their artistic life during the Soviet period or their underground activities. These in retrospect cannot be substantiated and they live on as oral commemorates. The most mythical of this generation of artists are e.g. Raul Meel, Leonhard Lapin and Matti Milius, who is active in art circles. Over this backdrop hover the shadows of Albert Trapeež and Matti Moguči.

\section{II - The Artist as Creator and the Creator as Divine Artist - Deus artifex - divino artista}

This motif is implicitly connected to the first one. In Plato's opinion only poetry and music rely on divine inspiration, the painter and sculptor must rely on their own skill and abilities in their work. In his dialogues "Io" the poet's inspiration is transferred to the reciter of the poetry. This person does not proceed from merely the rules of the art but rather from that self-same divine ecstasy that inspired the poetry.

However, we can find parallel to this the opposite tendency as well. In many of the creation myths around the world we can observe the actions of the creator described in terms of an artist at work. God is often represented as a blacksmith (Hephaestus, and an echo of this in the smith figure of the Finnish Ilmarinen as well as the Estonian song of the Golden Bride), builder or architect. We can easily find parallels to the artist at work in the Biblical myth of the creation of man and the subsequent creation of Eve from Adam's rib. The crea- 
tion of living creatures from a variety of different materials is without a doubt even more extensive than the creation of the protohumans themselves. Jaan Puhvel mentions wood, stone salmon teeth and other materials as the stuff that the Indo-European protopair are created from (Puhvel 1996: 285).

Such a down-to earth description of the creation of the world was particular popular during the middle ages. Erwin Panofsky has seen two tendencies at work here

- to make the creative work of God more graspable and approachable

- starting with the renaissance to compare God with an artist and thereby heroizing the work of the artist (Panofsky 1924).

The divine creator had many supernatural powers but in what way they were manifested was often dependent on the canons of the times. At this point we come to the third motif in which nature itself is described, on the one hand as the handiwork of God and, on the other hand as that of the artist. We can call this the Alberti's Approach although the idea of copying nature reaches back to the time of Plato and even further.

\section{III - the Artist as a Magician, the Ideal Copyist.}

Since nature is supreme, then the ideal of art is to be a copy of realty. We notice this motif again starting from ancient times. We run into it in the writings of Pliny the Elder many times. The bestknown of them is undoubtedly the story of Zeuxis and the Grapes:

[Parrhasius] decided to challenge Zeuxis who had painted a picture of some grapes with such virtuosity that birds had flown onto the stage set [where the picture was hanging]: With that Parrhasius made such a true-to-life picture of the curtains that Zeuxis, still so proud of the recognition he had received from the birds, asked that he pull the curtains from in front of his picture; but upon realizing his mistake he offered his own praises so humbly as to do him credit, saying that while he had been able to fool the birds then Parrhasius had been able to fool him. (Pliny the Elder 1952: 65-6, XXXV: 311.) 
Apparently this well-known story was one of the reasons for the general popularity of grapes in the later art of Europe. Pliny also writes about the stallion who tried to mount a picture of a mare painted by Apelles; or about a painted serpent that was able to stop the throats of birds or about a quail that flew onto a picture Protgenes had painted another quail into the background of. It would take too long to enumerate all the analogous stories from the renaissance, of which there are many about Titian, Dürer, Rafael and many others.

The best-known mythological development of this third motif is the falling in love with a figure depicted in a picture. We find it in fairy tales about a prince who falls in love with a portrait of a girl. We can recall myths form ancient Greece about the works of Daedalos and Praxiteles as well as Pygmalion. The best-known figure in literature is Oscar Wilde's A Portrait of Dorian Grey and the Estonian equivalent is the story of the Golden Bride. The further elaboration of this theme involves the anger of the gods who are jealous of the handiwork of these people (artists) - the myth of Prometheus as well as the Tower of Babel and the confusing of the languages of the earth that came about out of Gods fear of the greatness of a tower being erected by humans.

A fourth motif rises logically out of these three, mentioned by Kris and Kurz:

\section{IV - The Works and Deeds of Artists as a Divine Act}

We could say that art is one of the areas most prone to mythologization. The opinions of Kris and Kurz suggest an explanation that provides a good basis for understanding this affinity with myths that is empirically observable. The artist is a creator and in this way the mythical artist figure approaches godhood. The divine nature of a creator is what results in a work of art. It is the sacredness of the act of making a work of art (just as in Plato the divine flame of the poet is carried over to the person reciting the poem). This motif has in fact enabled us in the 20th century to progress relatively painlessly from an objectified art to a ritual of art and there is no difference in what the creator creates. 
Art has become heroically mythologised and serious. There is no place for carnival in great art. Perhaps this is the reason why the art world to this very day has not forgiven Dadaism for its rejection of the current myth of art or its deheroization of this myth. But Dada is an exceptional case. The myth, however, was not able to restore itself to the same extent that it once had existed.

The myth of art current today is characterized by the mission of art and the emphasis is placed on societal issues. The artist is a special mediator here, and again in a very Platonic way - not so much a creator/god anymore but rather as a priest/shaman. Today, art has assumed a burden which previously was not so obvious - it has an enormous appetite for money. Art is directly connected to its financiers and must justify somehow the societal luxury that it is. It is a matter of life and death for art. It is impossible to suggest that this is rational - but the nature of myth is always propped up by faith. When the artist creates a myth around him or herself, his or her life and works, then, when all is said and done, it is an expression of the belief in the legitimacy of his or her activities.

The mythic quality of art inevitably penetrates into the very metalanguage it uses - into art history and criticism. Art history differs from general history in that most usually it is about individual persons. A history that tries to achieve some semblance of objectivity and attempts to free itself from the narrative avoids the individual (see for example Ricoeur 1984: 193-206). Art history can never do that and as a result it is prone to fiction and myth. One of the bases for the mythic elements in the artist's biography is the selective quality of memory itself. Art history inevitably relies to a great extent on memory but the structure of memory often tends to be in the key of myth.

\section{3.}

In order to shed light on the nature of these myths it would be the most useful to compare the myths of art with the myths found and described in other fields of inquiry. Perhaps the comparable field might be science, a field that has traditionally been considered to be in opposition to art and religion. It has been quite common practice to compare science and poetry but here it seems that a com- 
parison with visual art might provide better results. Both science and poetry rely on natural language while pictorial art does not do so directly. And since one of the things that interested us initially was the linguistic qualities of myth, then this difference will become even more significant.

If art was at first felt to be a continuation of the narrative texture of the myth then the parallels to be found in science will have to be sought in its cognitive aspect. There is, of course, always the temptation here to grasp at the previous relationship between science and religion but, different from the myth of the artist, this is not essential to science. That firm sense of continuity does not exist since god has quietly disappeared from science.

It is the model, the schema taken as the basis of a hypothesis, the paradigm, that seems to be the most reminiscent of mythical texture in science. These are also connected to allegory as well as the rhetoric of scientific language (MacCormac 1976; Clarke 1996a \& 1996b; Paxson 1996; Weingart \& Maasen 1997). If a model has been adopted as the basis of a hypothesis, it becomes difficult to replace it. The model becomes an virtual symbol and a belief in its exclusive truth value is born. The distance between the model and reality disappears. In the sciences, fallacy is often conceived as myth.

A systematic attempt to examine the place of metaphor and myth in science appears in Earl R. MacCormac's book Metaphor and Myth in Science and Religion (MacCormac 1976). MacCormac concentrates essentially on metaphor. According to him, the myths in science grew out of metaphor. The fertile area for myths to grow out of lies in the so-called root metaphors, the conditional assumptions chosen as the basic hypotheses of a given theory which let us formulate the hypothetic descriptions of the world and our experiences (MacCormac 1976: xiv). Such root metaphors were, for example in Aristotelian physics, the direct physical force needed to put something in motion, the Newtonian 'the world is a machine' which was replaced by 'the world is mathematics' and 'the world is an organism' (MacCormac 1976: 122-126).

MacCormac suggests that in principle there is nothing to distinguish ritual from the testing of a hypothesis by means of experiment. For example, at one time pregnancy resulted from a fertility 
rite the belief in the rite was confirmed. If pregnancy did not come about, then the mistake was sought in the performance of the ritual and sub-hypotheses were formulated to help find the mistakes but the ritual itself was not rejected. The mechanisms of experimentation and computation in science actually function in the same way the ritual is performed in a laboratory. It is true that no attempt is made to actually alter things in the world through a series of experiments but the actual manifestation of anything real is accompanied by a firm belief that an experiment will confirm some aspect or other of the theory that has been taken as a basic assumption. Small failures do not hinder the continuation of this work (MacCormac 1976: 142-143).

If we do not associate myth necessarily with a false belief but rather simply with a belief in the validity of our own theories and practices then Thomas Kuhn's paradigm becomes all the more fused with the explanatory function of myth. Thomas Kuhn's (The Structure of Scientific Revolutions - Kuhn 1969) description of the development of science as consisting of a series of revolutions is of course merely schematic but it has attracted much debate although no one has completely negated the idea of a development of science that happens in jumps and leaps. Naturally some leaps are more intense than others (usually Copernicus, Newton or Einstein are referred to here). Ground needs to be broken for such leaps and conclusions made afterwards.

A hypothetic cross-section of the axioms dominant in science at various periods in time would reveal that the axioms differ one from the other in significant ways. It would be difficult in any given time to maintain the truth or falseness of one or another axiomatic belief but it is quite clear that it would be impossible at these given moments to conceive of the world in any other way. This synchronic view of the world and the impossibility of seeing beyond it is what we can compare to myth. Of course, in earlier times many actual mythological moments have been associated with the axiomatic beliefs such as Aristotles' motionless mover or God who remains a constant even within Newton's mechanics but this in no way diminishes the mythic quality of any given moment in the world view. The myth determines right from the start that no other view outside the given one is possible. 
The above can be summarised with two anecdotes: Einstein was once asked how inventions come about that could change the world. The famous physicist replied: "Very simply. Everyone knows that it's impossible to do something. By chance, some imbecile who doesn't know this comes along and he's the one who invents the thing. Or: Max Planck, one of the founders of Quantum theory, in his younger days went up to a 70-year old professor and confessed his intention to work in theoretical physics. "My dear boy," said the honourable old teacher, "Why would you want to wreck your life, theoretical physics has been finished. Is it worth working in a field that has no future."

The only thing speaking against such a concept of the myth of science is its small range - a limited number of people, very narrowly, the scientists in a given field. At the same time, nonetheless, the reverberations of 'high' science, however simplified and altered, end up in textbooks, journalism, etc. and generally it is at this level where the theory is accepted as belief (myth begins when belief begins). With this the mythical elements of science is spread. We are not in a position to demonstrate adequately the majority of what we know about our world. Even the majority of humanities people cannot convincingly prove Copernicus' views yet we do not doubt for a second that the Earth revolves around the Sun. Any explanation of the world, or view of the world, call it what you will, can inevitably only be conditional. Inevitably, something will be left on the threshold of cognition. After all, the majority of what we know is based on belief.

Another possibility of creating myths in the sciences is also connected with metaphors, but in a different way. It is clear that scientific language does not consist only of formulae, the main part of it is still based on natural language. But each new theory demands a new set of terms and the use of metaphor is thus quite typical. In examining scientific terminology we often find ourselves faced with concepts that have very thrilling and exciting stories behind them. This rhetoric is perhaps one of the essential elements in scientific language. A succinctly wrought new metaphoric term will attract the attention of the public and will pave the way for the dissemination of the new theory. 
These metaphoric concepts are, in their turn, the bases for new and exciting myths around the 'hard' sciences. The 'hard' disciplines and especially physics, sometimes more intensely, at other times less so, has enthralled thinkers from other fields since the science friendly years of the 60 's to the scepticism of the 80 's. Often the belief in the omnipotence of the sciences has assumed almost messianic proportions (Midgley 1992). The enchantment with the sciences has been the impetus for attempting to use the same theories in the humanities as well. This might also be one of the causes for mythifying metaphoric terms. Linguistically attractive but otherwise neutral concepts become symbols. One such example is the concept of entropy which was originally borrowed from thermodynamics and later in turn from information theory. Along with it came the second law of thermodynamics along with its negative aspects. The word entropy itself come from the usage of the German scientist Rudolf Clausius in 1865 who justified it as follows:

I prefer going to the ancient languages for the names of important scientific quantities so that they may mean the same thing in all living tongues. I propose, accordingly, to call S the entropy of a body, after the Greek word "transformation." I have designedly coined the word entropy to be similar to "energy," for these two quantities are so analogous in their physical significance, that an analogy of denomination seemed to me helpful. (Clarke 1996)

In borrowing the root trope the neologism 'entropy' brought a certain mytho-poetic backdrop into the transformation of energy, into the theory and from there back into the humanities. The entropy of thermodynamics became an allegory for culture.

We can recall from the not too distant past chaos theory and again we have a name with an ancient mythological background. In entering the humanities it acquired two mythological layers - the original and the 'hard' science one which seemed to augment one another. Chaos theory has been a captivating concept for some time already and some people have tried to find a parallel between it and deconstructivism (Hayles 1991; Kellert 1996; Matheson \& Kirchhoff 1997). An attempt has also been made to utilise it in literary research. The physics background of the word gives deconstructivism as if some guarantee of justification and conviction. 
While the narrative aspects of myth seem to dwell in art and its cognitive aspects are found in science, opposing currents can nonetheless be found in each. Many attempts are made to create epic proportions out of the cognitive aspects of myth in the humanities and in particular the fields of popular science. On the other hand, the myth of art cannot survive in just its narrative aspects. Inevitably the myth needs to be connected to the artist's belief in his or her own activities and in this way it achieves a connection with its cognitive dimensions.

\section{4.}

The contradictions in the multifaceted aspects of myth today which were referred to at the beginning of this paper can in part be reconciled by the three stages in the development of myth as outlined above.

Let us start from the end:

First of all there is myth in its classical definition, that is the myth of mythical consciousness whose poetic and cognitive aspects are not separated from each other.

As the second stage is myth that for some is alive but not for others. This means that there is some number of people who believe the myth and others (such as Barthes in the sense of the mythologist) who are able to determine the essence of the myth. This is the most heterogenous of the steps. This is where the continuation of the narrative scheme of classical myth in serial form as well as commercial myths, political myths and Barthes' bourgeois myths belong. It is possible to create this type of myth artificially but it can also come about as the result of determined activity or through the belief in the justification of the activity.

These myths are typically used for educational purposes. An attempt is made to show the world in a better light and to create positive figures. In the final analysis, art is the inalienable prerogative of this type, the fundamental myths in art are of just this type. 
I would call the third and last stage living myth. It is not possible to determine synchronically the essence of this myth type nor describe it - a living myth is determined by the knowledge current at the time within a given society and the belief in this knowledge. This myth lies at the edge of dankness since at any given moment no one is able to see further than this. Thus, this myth behaves in its own time in the same way as the first type in its time, that is in the time of mythical consciousness.

From the point of view of the people who live within it, the second level myth functions in the same way. Myth is in fact a typological concept and can remain so either inside or outside the concept itself. A living myth is not ideological since no ideology would have any use for it. A living myth encompasses in itself both Foucault's discourse as well as Kuhn's paradigm. In some ways it is the basis for a functioning society.

The living myth crosses over into the next stage right away when it is possible to recognise its existence, that is when it is possible to step outside the myth. As soon as it is possible to define the myth as a myth, the myth begins to die and a new must replace it - existence without myths is not possible. Barthes' mythologist did nothing but replace old myths with new ones. At the time of his mythologies, the new mythology was the political left.

I would not consider the living myth as being asemiotic but rather as being presemiotic. The recognition of the myth and the stepping outside the bounds of the myth allows us to describe the myth and cause it to become a text. We could say that people discuss living myths which means that they talk about what they know as the myth is functioning. In reality they are not discussing the myth but rather maintaining a dialogue with it and they can only speak using the words of faith in the language of faith. Myth is the addressee just as in a dialogue with God, the words are directed at the one whose name is unknown.

The living myth does not require faith or rather intention. It functions on its own and encompasses us in our passivity. This is what distinguishes myth from message since communication inevitably requires activity on the part of the recipient. Blind faith in myth is the opposite of word. Myth is not a message, myth is a preverbal 
state even if it is able to utilize words as an aid. When myth dies its words are left behind. A verbalised myth is a dead myth.

Living myth is presemiotic in the sense that it is lacking any characteristics of language. The essence of language even in its most metaphoric sense presupposes the recognition of some sort of system of signs. In order to identify the essence of language we need not know the meaning but we do have to be convinced that some assignment of signs is happening. In the case of living myth, this is not possible. We are inside the denotation and we cannot understand what is determining meaning and that this is happening at all. In Pierce's terminology we might say that living myth lacks an interpretant. The apparent lack of a myth makes it presemiotic and ineligible to having meaning assigned to it. Only when myth becomes text can it become apparent and existent.

Translated by Harri Mürk.

\section{Comments}

${ }^{1}$ 1. The Sheldon Memorial Art Gallery (20. VI 2001):

http://sheldon.unl.edu/HTML/ARTIST/Rothko_M/SSI.html

2. London Tate Gallery (20. VI 2001):

http://www.tate.org.uk/servlet/ArtistBio?id=1959

3. Encyclopaedia Britannica (20. VI 2001): http://www.britannica.com/

4. Washington, National Gallery of Art (28.V 1999):

http://www.nga.gov/feature/rothko/early1.html

${ }^{2}$ http://www.nga.gov / feature / pollock/artist1.html 28.V 1999 (for the present changed).

\section{References}

Barthes, Roland (1957) 1982. Myth Today. A Barthes Reader. Susan Sontag (ed.). London: Jonathan Cape, pp. 93-150.

Clarke, Bruce 1996a. Introduction: Allegory and Science. Configurations, 4 (1), pp. 33-37.

Clarke, Bruce 1996b. Allegories of Victorian Thermodynamics. Configurations, 4 (1), pp. 67-90.

Eliade, Mircea 1963. Myth and Reality. Trans. Williard R. Trask. New York: Harper \& Row.

Hayles, Katherine N. (ed.) 1991. Chaos and Order: Complex Dynamics in Literature and Science. Chicago: University of Chicago Press. 
Kasak, Enn 1995. Navitrolla elu lugu, pajatuste ja legendidega. Navitrolla esimene raamat. Tallinn: Huma, pp. 20-26.

Kellert, Stephen H. 1996. Science and Literature and Philosophy: The Case of Chaos Theory and Deconstruction. Configurations, 4 (2), pp. 215232.

Kris, Ernst \& Kurz, Otto 1979.Legend, Myth, and Magic in the Image of the Artist. Trans. Alastair Laing, Lottie M. Newman. New Haven, London: Yale University Press.

Kuhn, Thomas 1969. The Structure of Scientific Revolutions. 2nd ed. Chicago: University of Chicago Press.

Lévi-Strauss, Claude (1964) 1970. The Raw and the Cooked. Introduction to a Science of Mythology I. Trans. John ja Doreen Weightman. London: Jonathan Cape.

Lévi-Strauss, Claude (1958) 1972. Structural Anthropology. Trans. Claire Jacobson, Brooke Grundfest Schoepf. London: Penguin Books.

Lotman, Yuri \& Uspenski, Boris 1992. Mif - imia - kultura. Izbrannye stat'i I. Y. M. Lotman (ed.). Tallinn: Aleksandra, pp. 58-75.

MacCormac, Earl R. 1976. Metaphor and Myth in Science and Religion. Durham: Duke University Press.

Mallen, Enrique 1999a. Picasso: Childhood of A Genius. On-Line Picasso Project. http://www.tamu.edu/mocl/picasso/biog/childh.html, 28. V 1999.

Mallen, Enrique 1999b. Pablo Picasso: Life and Career. On-Line Picasso Project. http://www.tamu.edu/mocl/picasso/biog/piclife.html, 28. V 1999.

Matheson, Carl; Kirchhoff, Evan 1997. Chaos and Literature. Philosophy and Literature, 21 (1), pp. 28-45.

Midgley, Mary, 1992.Science as Salvation: A Modern Myth and its Meaning. London, New York: Routledge.

Panofsky, Erwin 1924.Idea: Ein Beitrag zur Begriffsgeschichte der älteren Kunsttheorie. Studien der Bibliothek Warburg V. Leipzig.

Paxson, James J. 1996. The Allegory of Temporality and the Early Modern Calculus. Configurations, 4 (1), pp. 39-66.

Pliny 1952. Natural History. Trans. H. Rackham. Vol. IX, Libri XXXIIIXXXV. Cambridge, Massachusetts: Harvard University Press.

Puhvel, Jaan 1996. Võrdlev mütoloogia. Tartu: Ilmamaa.

Ricoeur, Paul 1984. Time and Narrative I. Trans. Kathleen McLaughlin, David Pellauer. Chicago, London: University of Chicago Press.

Sorel, Georges (1908) 1990. Réflexions sur la violence. Paris: Éditions du Seuil.

Stryk, Friedrich von 1918. Kunstiühingu "Pallas'e" näitus. "Postimehe" Lisa, nr. 16, lk. 134-135.

Vasari, Giorgio 1927. The Lives of the Painters, Sculptors and Architects. I-IV. Trans. A. B. Hinds. London, Toronto: J. M. Dent \& Sons.

Weingart, Peter \& Maasen, Sabine 1997. The Order of Meaning: The Career of Chaos as a Metaphor. Configurations, 5 (3), pp. 463-520.. 